\title{
Optimization of the Emitting Coil of a Hardware-Software Complex for Study of Low-Frequency Electromagnetic Radiation's Shielding Effectiveness
}

\author{
O.D. Kanafyev ${ }^{1}$, A.V. Trukhanov ${ }^{1}$, T.I. Zubar ${ }^{1}$, S.A. Chizhik ${ }^{2}$, S.S. Grabchikov ${ }^{1}$ \\ ${ }^{1}$ Scientific and Practical Materials Research Center of the National Academy of Sciences of Belarus, \\ P. Brovki str., 19, Minsk 220072, Belarus \\ ${ }^{2}$ National Academy of Sciences of Belarus, \\ Nezavisimosty Ave., 66, Minsk 220072, Belarus
}

Received 14.12.2020

Accepted for publication 22.02.2021

\begin{abstract}
Optimization of the radiation coil of the hardware-software complex for studying the effectiveness of shielding of low-frequency electromagnetic radiation will make it possible to assess the effectiveness of shielding coatings at a higher level. This fact will make it possible to develop coatings with improved characteristics. The purpose of this work was to determine the optimal characteristics of the emitting coil which will ensure its stable operation and magnetic field strength in the frequency range up to $100 \mathrm{kHz}$.

The parameters of the manufactured samples, such as inductance $(L)$, active $(R)$ and total resistance $(Z)$, were obtained using an MNIPI E7-20 emittance meter. In practice, the coils with the optimal parameters calculated theoretically were connected to a current source and amplifier. To detect electromagnetic radiation, a multilayer inductor connected to a UTB-TREND 722-050-5 oscilloscope was used as a signal receiver.

The results of measurements showed that the resistance of multilayer coils is approximately 1000 times higher than that of single-layer coils. Also, for multilayer coils, an avalanche-like increase in total resistance is observed starting from a frequency of $10 \mathrm{kHz}$, while for single-layer coils there is a uniform increase in total resistance over the entire frequency range up to $100 \mathrm{kHz}$.

The paper presents results of research on the correlation of the performance of single-layer and multilayer inductors depending on their parameters in the frequency range from $20 \mathrm{~Hz}$ to $100 \mathrm{kHz}$. Values of the voltage required to provide the magnetic field strength of 1, 5, 20 Oe at $25 \mathrm{~Hz}$ and $100 \mathrm{kHz}$ have been calculated. After analyzing the data obtained, the optimal parameters of the inductor were found which ensure stable performance in the frequency range up to $100 \mathrm{kHz}$.
\end{abstract}

Keywords: inductor coil, shielding, electromagnetic emitting.

DOI: $10.21122 / 2220-9506-2021-12-1-30-37$

\author{
Адрес для переписки: \\ Канафьев О.Д. \\ НПЦ НАН Беларуси по материаловедению, \\ ул. П. Бровки, 19, г. Минск 220072, Беларусь \\ e-mail:olegkan96@mail.ru
}

\author{
Address for correspondence: \\ Kanafyev O.D. \\ Scientific and Practical Materials Research Center of the National \\ Academy of Sciences of Belarus, \\ P. Brovki str., 19, Minsk 220072, Belarus \\ e-mail: olegkan96@mail.ru \\ For citation: \\ O.D. Kanafyev, A.V. Trukhanov, T.I. Zubar, S.A. Chizhik, S.S. Grabchikov. \\ Optimization of the Emitting Coil of a Hardware-Software \\ Complex for Study of Low-Frequency Electromagnetic Radiation's \\ Shielding Effectiveness. \\ Devices and Methods of Measurements. \\ 2021, vol. 12 , no. 1 , pp. $30-37$. \\ DOI: $10.21122 / 2220-9506-2021-12-1-30-37$
}

Для цитирования:

O.D. Kanafyev, A.V. Trukhanov, T.I. Zubar, S.A. Chizhik, S.S. Grabchikov.

Optimization of the Emitting Coil of a Hardware-Software 


\title{
Оптимизация излучающей катушки программно- аппаратного комплекса для исследования эффективности экранирования низкочастотного электромагнитного излучения
}

\author{
О.Д. Канафьев ${ }^{1}$, А.В. Труханов ${ }^{1}$, Т.И. Зубарь ${ }^{1}$, С.А.Чижик ${ }^{2}$, С.С. Грабчиков ${ }^{1}$ \\ ${ }^{1}$ Научно-практический цุентр Нацฺиональной академии наук Беларуси по материаловедению, \\ ул. П. Бровки, 19, г. Минск 220072, Беларусь \\ ${ }^{2}$ Национальная Академия наук Беларуси, \\ пр-т Независимости, 66, г. Минск 220072, Беларусь
}

Поступила 14.12.2020

Принята к печати 22.02.2021

Оптимизация излучающей катушки программно-аппаратного комплекса для исследования эффективности экранирования низкочастотного электромагнитного излучения позволит на более качественном уровне оценивать эффективность экранирующих покрытий. Данный факт даст возможность разрабатывать покрытия с улучшенными характеристиками. Целью данной работы являлось определение оптимальных характеристик излучающей катушки, которые обеспечат её стабильную работу и напряжённость магнитного поля в частотном диапазоне до 100 кГц.

Параметры изготовленных образцов, такие как индуктивность, активное и общее сопротивление, были получены, используя измеритель иммитанса МНИПИ Е7-20. На практике катушки с оптимальными параметрами, вычисленными теоретически, были подключены к источнику и усилителю тока. Для детектирования электромагнитного излучения в качестве приёмника сигнала использовалась многослойная катушка индуктивности, подключённая к осциллографу UTB- TREND 722-050-5.

Результаты измерений показали, что сопротивление многослойных катушек приблизительно в 1000 раз больше сопротивления однослойных. Также у многослойных катушек наблюдается лавинообразный рост общего сопротивления, начиная с частоты 10 кГц, в то время как у однослойных катушек происходит равномерный рост общего сопротивления на всём диапазоне частот до 100 кГц.

Представлены результаты исследований корреляции рабочих характеристик однослойных и многослойных катушек индуктивности в зависимости от их параметров в частотном диапазоне от 20 Гц до 100 кГц. Рассчитаны значения напряжения, необходимого для обеспечения напряжённости магнитного поля 1, 5, 20 Э при 25 Гц и 100 кГц. Проанализировав полученные данные, найдены оптимальные параметры катушки индуктивности, обеспечивающие стабильные рабочие характеристики в диапазоне частот до 100 кГц.

Ключевые слова: катушка индуктивности, экранирование, электромагнитное излучение.

DOI: $10.21122 / 2220-9506-2021-12-1-30-37$

\begin{tabular}{ll}
\hline Адрес для переписки: & Address for correspondence: \\
Канафьев О.Д. & Kanafyev O.D. \\
НПЦНАН Беларуси по материаловедению, & Scientific and Practical Materials Research Center of the National \\
ул. П. Бровки, 19, г. Минск 220072, Беларусь & Academy of Sciences of Belarus, \\
e-mail: olegkan96@mail.ru & P. Brovki str., 19, Minsk 220072, Belarus \\
& e-mail: olegkan96@mail.ru \\
\hline Для цитирования: & For citation: \\
O.D. Kanafyev, A.V. Trukhanov, T.I. Zubar, S.A. Chizhik, S.S. Grabchikov. & O.D. Kanafyev, A.V. Trukhanov, T.I. Zubar, S.A. Chizhik, S.S. Grabchikov. \\
Optimization of the Emitting Coil of a Hardware-Software & Optimization of the Emitting Coil of a Hardware-Software \\
Complex for Study of Low-Frequency Electromagnetic Radiation's & Complex for Study of Low-Frequency Electromagnetic Radiation's \\
Shielding Effectiveness. & Shielding Effectiveness. \\
Приборы и методы измерений. & Devices and Methods of Measurements. \\
2021. - Т. 12, № 1. - С. 30-37. & 2021, vol. 12, no. 1, pp. 30-37. \\
DОI: 10.21122/2220-9506-2021-12-1-30-37 & DOI: 10.21122/2220-9506-2021-12-1-30-37 \\
\hline &
\end{tabular}




\section{Introduction}

A great threat to the security of information on electronic devices, sensitive elements of various devices, biological objects is created by electromagnetic radiation of various nature. Sources of electromagnetic radiation in everyday life are household appliances, electric vehicles, mobile phones and other electronic devices $[1,2]$. To protect against electromagnetic radiation, there are active and passive methods [3]. The passive method is to use screens that absorb or reflect electromagnetic radiation (EMR). For passive protection materials with high magnetic permeability are used. With the help of passive screens it is possible to protect certain sensitive elements of the device, and these screens are easy to use and more profitable in economic terms. However, at the moment there is no unified method for analyzing the effectiveness of shielding. Most scientific papers consider the effect of low-frequency EMR on living organisms and plants without affecting the analysis of the effectiveness of screens.

Analysis of information on the topic of this work shows that there are no standardized generally accepted methods for assessing the effectiveness of shielding [5-7]. To assess the shielding properties of various materials a device or apparatus with a sufficiently powerful emitter of electromagnetic radiation is required which stably operates both with direct and alternating currents of various frequencies. Inductors [8] can be used as such as an emitter, varying the parameters of which the required result can be achieved.

The purpose of this work was to manufacture inductor coils with different parameters, study their characteristics, and determine a sample that provides stable electromagnetic radiation in the frequency range from $25 \mathrm{~Hz}$ to $100 \mathrm{kHz}$. The sample coil with optimal parameters will be used in the hardwaresoftware complex as an emitter and will allow to obtain new, unique data on the shielding efficiency of magnetic coatings and multilayer structures based on them, as well as to compare the previously obtained data on the shielding efficiency in a constant magnetic field with new data that will be obtained with alternating electromagnetic radiation.

\section{Measurement technique}

Single-layer and multi-layer inductors were manufactured as prototypes. For the manufacture of single-layer inductors copper wire with a cross section of 1 and $2 \mathrm{~mm}$ was used. The inner diameter $(d)$ of the coils was 7 and $15 \mathrm{~mm}$, the number of turns $(N)$ was from 6 to 41, and the length $(l)$ was from 15 to $65 \mathrm{~mm}$. Multilayer coils were made from copper wire with a diameter of $0.1 ; 0.18$ and $0.35 \mathrm{~mm}$. The coils diameter was $6 \mathrm{~mm}$, the number of turns was from 1000 to 6000 , and the length was from 20 to $120 \mathrm{~mm}$. Detailed information about the samples' parameters is presented in Table 1.

Table 1

\section{Parameters of inductors}

\begin{tabular}{|c|c|c|c|c|c|}
\hline № & $\begin{array}{c}\text { Coil } \\
\text { designation }\end{array}$ & $\begin{array}{c}d, \\
\mathrm{~mm}\end{array}$ & $N$ & $l, \mathrm{~mm}$ & $\begin{array}{c}t, \\
\mathrm{~mm}\end{array}$ \\
\hline \multicolumn{6}{|c|}{ Single layer coils } \\
\hline 1 & $S L \_N 6 \_t 2 \_d 7$ & 7 & 6 & 15 & \multirow{10}{*}{2} \\
\hline 2 & $S L \_N 11 \_t 2 \_d 7$ & 7 & 11 & 25 & \\
\hline 3 & $S L \_N 14 \_t 2 \_d 7$ & 7 & 14 & 35 & \\
\hline 4 & $S L \_N 18 \_t 2 \_d 7$ & 7 & 18 & 45 & \\
\hline 5 & $S L \_N 28 \_t 2 \_d 7$ & 7 & 28 & 65 & \\
\hline 6 & $S L \_N 6 \_t 2 \_d 15$ & 15 & 6 & 15 & \\
\hline 7 & $S L \_N 11 \_t 2 \_d 15$ & 15 & 11 & 25 & \\
\hline 8 & $S L \_N 13 \_t 2 \_d 15$ & 15 & 13 & 35 & \\
\hline 9 & $S L \_N 18 \_t 2 \_d 15$ & 15 & 18 & 45 & \\
\hline 10 & $S L \_N 27 \_t 2 \_d 15$ & 15 & 27 & 65 & \\
\hline \multicolumn{6}{|c|}{ Multilayer coils } \\
\hline 1 & $N 4-t .1-d 6$ & 6 & 4000 & 20 & 0.1 \\
\hline 2 & $N 1-t .18-d 6$ & 6 & 1000 & 19.6 & 0.18 \\
\hline 3 & $N 8-t .15-d 6$ & 6 & 8000 & 22 & 0.15 \\
\hline 4 & $N 2-t .35-d 6$ & 6 & 2000 & 70 & 0.35 \\
\hline 5 & $N 4-t .35-d 6$ & 6 & 4000 & 100 & 0.35 \\
\hline 6 & $N 6-t .35-d 6$ & 6 & 6000 & 120 & 0.35 \\
\hline
\end{tabular}

The manufactured samples' parameters, such as inductance $(L)$, active $(R)$ and total resistance $(Z)$ were obtained using an MNIPI E7-20 emittance meter. In practice, the coils with the optimal parameters calculated theoretically were connected to a current source and amplifier. To detect electromagnetic radiation a multilayer inductor connected to a $U T B$ TREND 722-050-5 oscilloscope was used as a signal receiver.

\section{Results and discussion}

As can be seen from the graphs (Figure 1), the $S L+N 6 t 2 \_d 7$ coil has the lowest inductance among the coils with an inner diameter of $7 \mathrm{~mm}$. Among 
the coils with an inner diameter of $15 \mathrm{~mm}$, the $S L \_N 6 \_t 2 \_d 15$ coil has the smallest inductance. The inductance of the first sample increases from 0.1 to $0.2 \mu \mathrm{H}$ in the frequency range from $25 \mathrm{~Hz}$ to $100 \mathrm{kHz}$, while the inductance of the second sample is stable over the entire frequency range and equals $0.5 \mu \mathrm{H}$. Despite the large inductance the $S L_{-} N 6 \_t 2 d 15$ coil looks preferable to the $S L_{-} N 6_{-} t 2 \_\bar{d} \overline{7}$ one, because it has a constant inductance value over the entire frequency range.
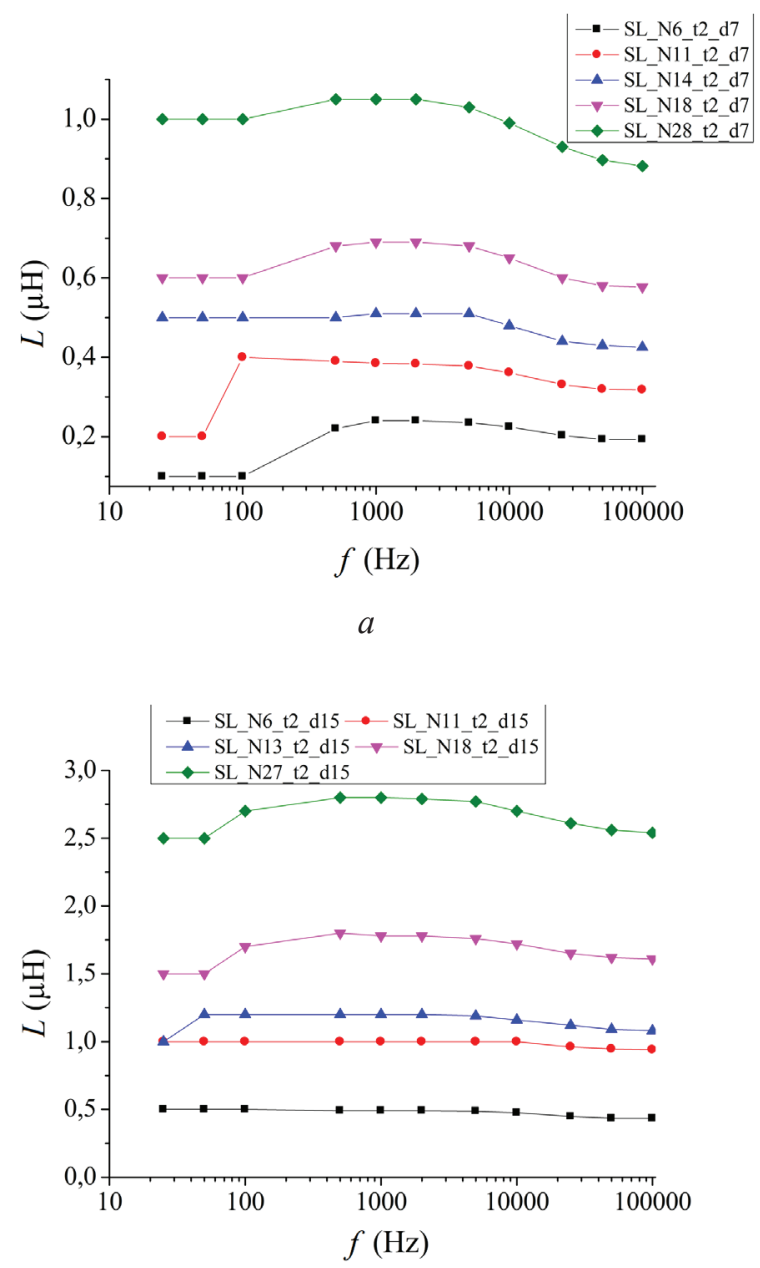

$b$

Figure 1 - Dependence of the inductance of single-layer coils on the current frequency: $a$ - coil diameter $7 \mathrm{~mm}$; $b$ - coil diameter $15 \mathrm{~mm}$

Figure 2 shows that all samples with an inner diameter of 7 and $15 \mathrm{~mm}$ have constant resistance values $R$ at frequencies from $25 \mathrm{~Hz}$ to $5 \mathrm{kHz}$. After $5 \mathrm{kHz}$ a sharp increase in resistance is observed in almost all samples, with the exception of samples $S L N 6$ t2 $d 7, S L N 11$ t2 $d 7$ and SL N6 t2 $d 15$. This is most likely due to the skin effect [9] which consists in the fact that the currents flowing on the surface of the wire screen the inner layers, as a result of which almost all current is concentrated in a thin surface layer. The proximity effect also contributes, the essence of which is that eddy currents arise in the coil wire under the influence of a magnetic field from adjacent turns [10].

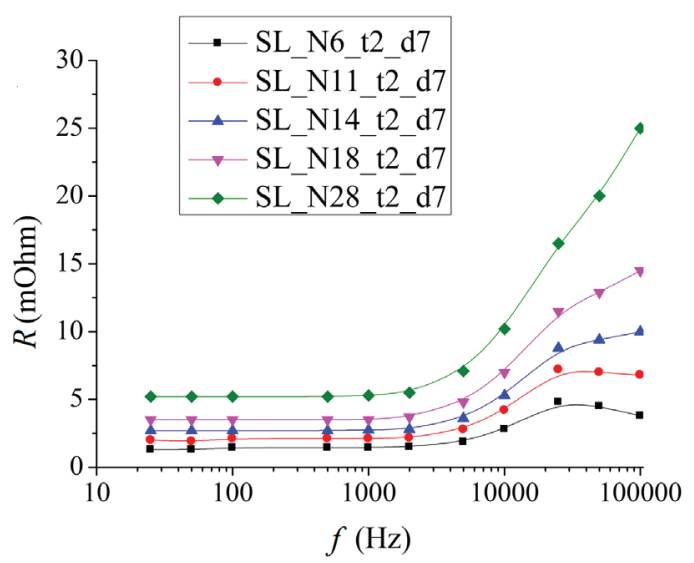

$a$

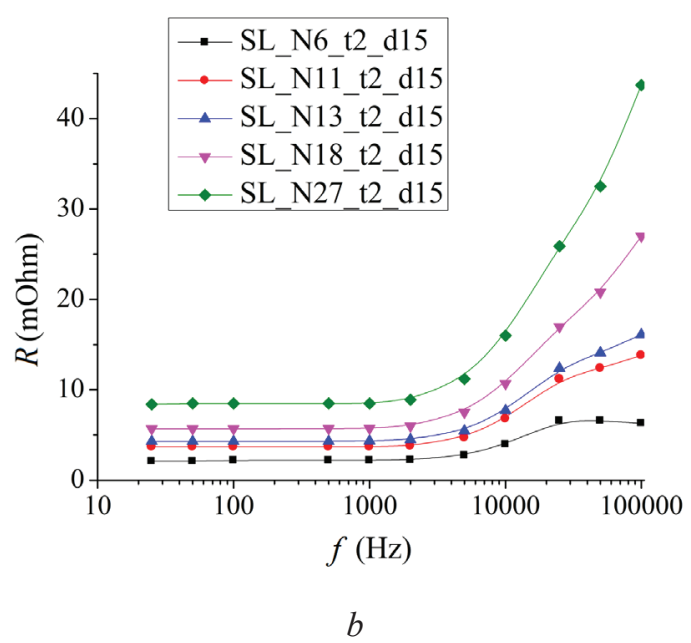

Figure 2 - Dependence of the resistance of single-layer coils on the current frequency: $a$-coil diameter $7 \mathrm{~mm}$; $b$-diameter of coils $15 \mathrm{~mm}$

Figure 3 shows that the total resistance of all coils increases linearly. Coils $S L \_N 6 \_t 2 \_d 7$ and $S L+N 6 \_t 2 d 15$ have the lowest total resistance. This is probably due to the fact that these coils have fewer turns, respectively, in their manufacture, a shorter wire length is used compared to the rest of the samples.

These graphs show that the inductance $L$ for coils with a diameter of $7 \mathrm{~mm}$ and a wire thickness 
of $2 \mathrm{~mm}$ does not change significantly at $100 \mathrm{~Hz}$. For coils with a diameter of $15 \mathrm{~mm}$ and a wire thickness of $2 \mathrm{~mm}$, as well as for coils with a diameter of $7 \mathrm{~mm}$ and a wire thickness of $1 \mathrm{~mm}$, the inductance $L$ practically does not change at frequencies up to $100 \mathrm{kHz}$.

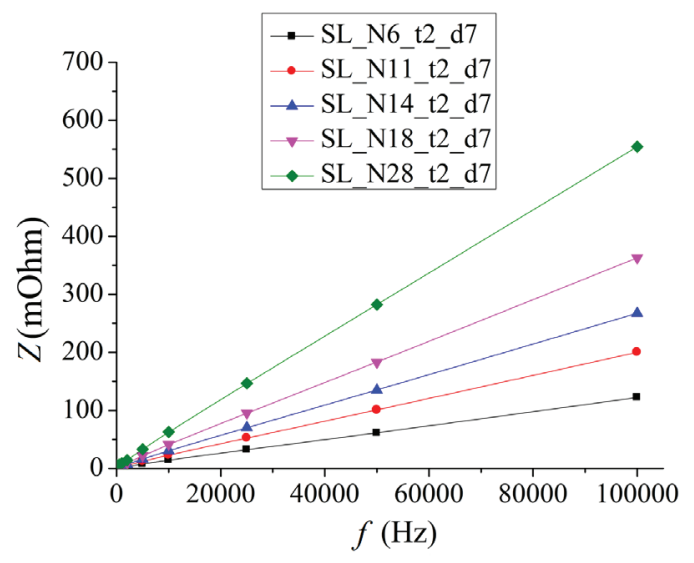

$a$

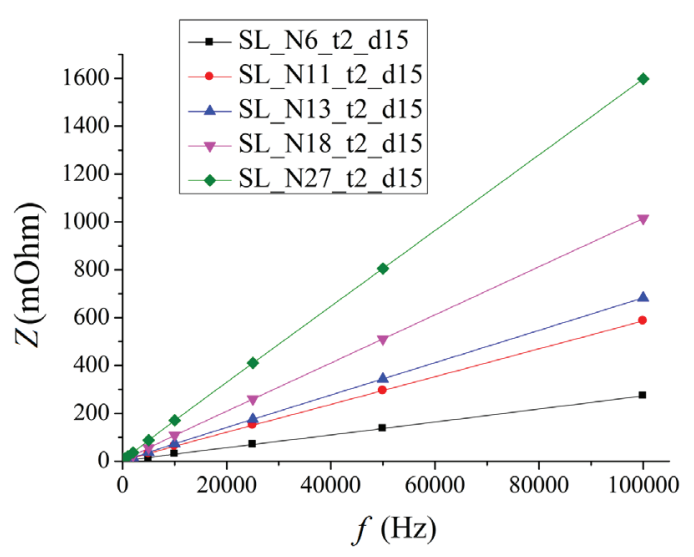

$b$

Figure 3-Graphs of the dependence of the total resistance of single-layer coils on the current frequency: $a$ - coil diameter $7 \mathrm{~mm}$; $b$ - coil diameter $15 \mathrm{~mm}$

Coils with a diameter of 7 and $15 \mathrm{~mm}$ and a wire thickness of $2 \mathrm{~mm}$ have less resistance than coils with a diameter of $7 \mathrm{~mm}$ and a wire thickness of $1 \mathrm{~mm}$. At the same time, for all coils a slight increase in resistance is observed over the entire frequency range up to $100 \mathrm{kHz}$. The total resistance of all single-layer coils increases linearly with increasing emitting frequency.

Figure 4 shows that some of the multilayer coils have constant inductance values over the entire frequency sample. The second part of the samples shows unpredictable inductance values. It can be assumed that this is due to the large number of turns in the coils, some of which may have insulation defects.

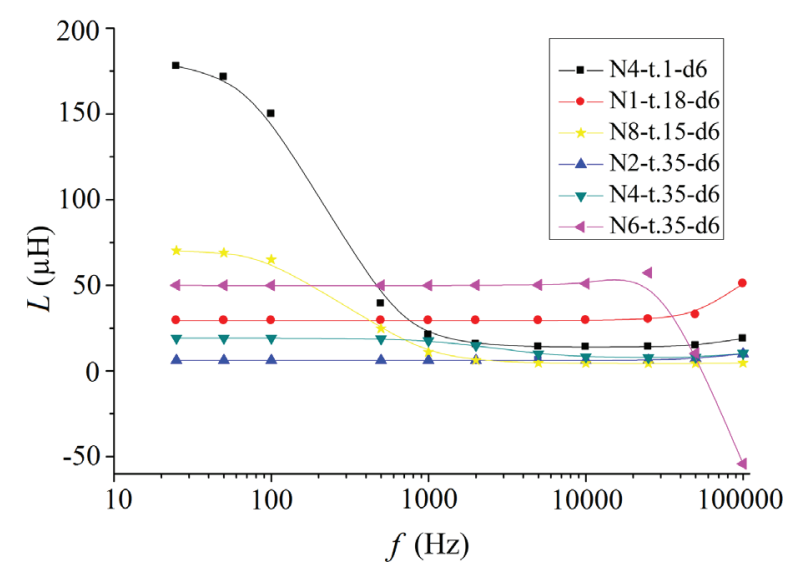

Figure 4-Graph of the dependence of the inductance of multilayer coils on the current frequency

As seen in Figure 5, the resistance of multilayer coils is constant from $25 \mathrm{~Hz}$ to $10 \mathrm{kHz}$. After $10 \mathrm{kHz}$, an avalanche-like increase in resistance occurs. Coils N4-t.1-d6 and N1-t.18-d6 come into resonance due to the presence of skin and proximity effects. Parasitic capacitances also increase strongly at high frequencies. These capacitances, in combination with the high inductance of the coil, transform it into a whole chain of oscillatory circuits with resonances falling within the operating range or even below it, and then the coil acquires capacitive resistance.

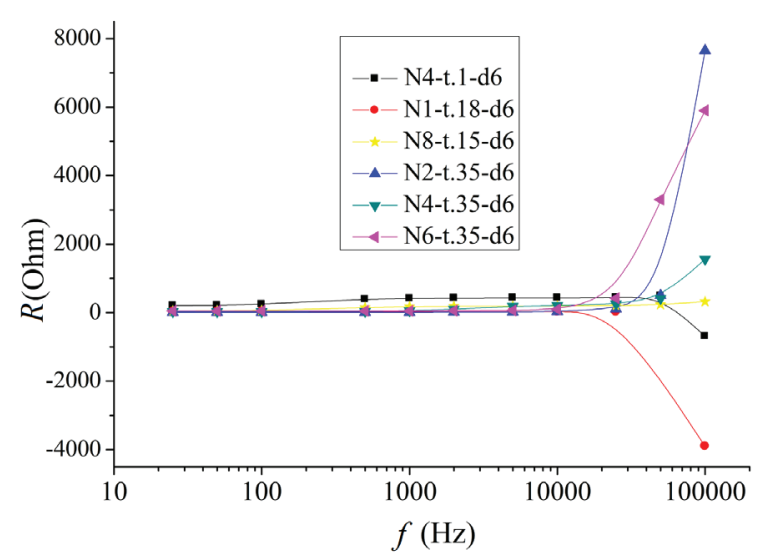

Figure 5-Dependence of the resistance of multilayer coils on the frequency of the current

Figure 6 presents that the total resistance of all samples has a constant value from $25 \mathrm{~Hz}$ to $5 \mathrm{kHz}$, after $5 \mathrm{kHz}$ there is a rapid increase in the total resistance. This is due to the presence of a skin effect and a proximity effect. These effects are much more 
pronounced with multilayer coils, due to the longer winding length and also due to the large number of turns.

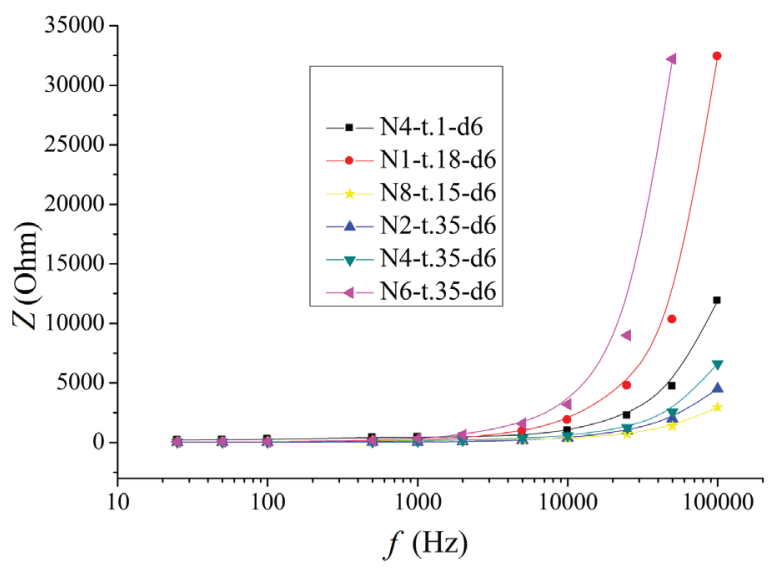

Figure 6-Dependence of the total resistance of multilayer coils on the frequency of the current

Analyzing the graphs, we can conclude that all multilayer coils for the entire frequency sample have a constant inductance, except for two samples. At an electromagnetic field frequency of up to $10 \mathrm{kHz}$, multilayer coils have constant resistance. At a current frequency above $50 \mathrm{kHz}$, the resistance of all samples begins to increase sharply. The total resistance of the coils begins to increase when the frequency of the electromagnetic field is over $10 \mathrm{kHz}$.

The values of the magnetic field strength inside the cylindrical coil $H(E)$ for the manufactured samples of inductance coils were calculated by the formula:

$I=\frac{I n}{l}$,

where $I$ - the current in the coil; $n$ - the number of turns of the coil; $l$ - the length of the coil;

$I=\frac{U}{Z}$,

where $U-$ the voltage applied to the circuit section; $Z$ - impedance measured with an RLC meter.

Table 2

Calculation results of the voltage required to ensure the magnetic field strength of $1,5,20$ Oe for single-layer coils

\begin{tabular}{|c|c|c|c|c|c|c|c|}
\hline \multirow{2}{*}{ № } & \multirow{2}{*}{ Coil designation } & \multicolumn{2}{|c|}{$U_{1 \mathrm{Oe}}, \mathrm{V}$} & \multicolumn{2}{|c|}{$U_{5 \mathrm{Oe}}, \mathrm{V}$} & \multicolumn{2}{|c|}{$U_{20 \text { Oe }}, \mathrm{V}$} \\
\hline & & $25 \mathrm{~Hz}$ & $10 \mathrm{kHz}$ & $25 \mathrm{~Hz}$ & $10 \mathrm{kHz}$ & $25 \mathrm{~Hz}$ & $10 \mathrm{kHz}$ \\
\hline 1 & $S L \_N 6 \_t 2 \_d 7$ & 0.00026 & 0.0245 & 0.0013 & 0.1225 & 0.005174 & 0.48755 \\
\hline 2 & $S L \_N 11 \_t 2 \_d 7$ & 0.00042 & 0.04002 & 0.0021 & 0.2001 & 0.0084 & 0.8004 \\
\hline 3 & $S L \_N 14 \_t 2 \_d 7$ & 0.00054 & 0.05346 & 0.0027 & 0.2673 & 0.0108 & 1.0692 \\
\hline 4 & $S L \_N 18 \_t 2 \_d 7$ & 0.0007 & 0.07256 & 0.0035 & 0.3628 & 0.01323 & 1.371384 \\
\hline 5 & $S L \_N 28 \_t 2 \_d 7$ & 0.000988 & 0.105374 & 0.004836 & 0.515778 & 0.01924 & 2.05202 \\
\hline 6 & $S L \_N 6 \_t 2 \_d 15$ & 0.00042 & 0.05468 & 0.0021 & 0.2734 & 0.0084 & 0.2734 \\
\hline 7 & $S L \_N 11 \_t 2 \_d 15$ & 0.000648 & 0.10548 & 0.003276 & 0.53326 & 0.013104 & 2.13304 \\
\hline 8 & $S L \_N 13 \_t 2 \_d 15$ & 0.000946 & 0.150194 & 0.004644 & 0.737316 & 0.01849 & 2.93561 \\
\hline 9 & $S L \_N 18 \_t 2 \_d 15$ & 0.00114 & 0.2028 & 0.0057 & 1.0142 & 0.0228 & 4.0568 \\
\hline 10 & $S L \_N 27 \_t 2 \_d 15$ & 0.00042 & 0.05468 & 0.002016 & 0.262464 & 0.008085 & 1.05259 \\
\hline
\end{tabular}

For the stable operation of the electromagnetic radiation at different frequencies, it is required to vary the values of the emitting supplied to the coils. The tables above show the 
voltage values calculated to provide magnetic field strengths of $1,5,20 \mathrm{Oe}$ in the frequency range from $25 \mathrm{~Hz}$ to $100 \mathrm{kHz}$, for single-layer and multilayer coils.

Table 3

Calculation results of the voltage required to ensure the magnetic field strength of $1,5,20$ Oe multilayer coils

\begin{tabular}{lccccccc}
\hline \multirow{2}{*}{$№$} & Coil designation & \multicolumn{2}{c}{$U_{1 \mathrm{Oe}}, \mathrm{V}$} & \multicolumn{2}{c}{$U_{5 \mathrm{Oe}}, \mathrm{V}$} & \multicolumn{2}{c}{$U_{20 \mathrm{Oe}}, \mathrm{V}$} \\
\cline { 3 - 7 } & $25 \mathrm{~Hz}$ & $10 \mathrm{kHz}$ & $25 \mathrm{~Hz}$ & $10 \mathrm{kHz}$ & $25 \mathrm{~Hz}$ & $10 \mathrm{kHz}$ \\
\hline 1 & $N 4-t .1-d 6$ & 0.08424 & 4.76 & 0.4212 & 23.8 & 1.6848 & 95.2 \\
2 & $N 1-t .18-d 6$ & 0.04680 & 5.13 & 0.23648 & 59.2 & 0.94592 & 136.8 \\
3 & $N 2-t .35-d 6$ & 0.038136 & 12.6 & 0.19068 & 63 & 0.76272 & 252 \\
4 & $N 4-t .35-d 6$ & 0.05794 & 13.22 & 0.2897 & 66.1 & 1.1588 & 264.4 \\
5 & $N 6-t .35-d 6$ & 0.08352 & 42.24 & 0.4176 & 211.2 & 1.6704 & 844.8 \\
\hline
\end{tabular}

Analyzing the data obtained, we can say that to ensure the operation of multilayer coils, a much higher voltage is required compared to single-layer coils. This is due to the high values of the inductance of multilayer coils as well as the presence of skin and proximity effects. Single-layer coils are also subject to these disadvantages but to a much lesser extent. In addition the voltage values required to operate at 20 Oe of multilayer coils are likely to be critical. Difficulties also arise with the selection of a voltage source operating in such a wide range of values.

\section{Conclusion}

Investigations of single-layer and multilayer inductors with different parameters have been carried out.

It was found that it is preferable to use single-layer inductors as a source of electromagnetic radiation operating in the frequency range up to $100 \mathrm{kHz}$. At a frequency from 10 to $100 \mathrm{kHz}$, an avalanchelike increase in total resistance begins in multilayer inductors; when measuring the active resistance, some samples enter into resonance. This is due to the presence of skin and proximity effects, which are pronounced in multilayer samples, due to a much larger number of turns, as well as their tightness. The inductance of multilayer coils is 1000 times higher than single-layer coils, as a result of which parasitic capacitances increase significantly. The combination of the factors given above transform a multilayer coil into a chain of oscillatory circuits with resonances often falling into the operating range or below it.
Due to the use of a wire with a cross section of $2 \mathrm{~mm}$ for winding single-layer coils, the active resistance of these samples is approximately 1000 times less than that of multilayer coils. Also, due to this fact, much lower values of the applied voltage are required to provide a power of electromagnetic radiation similar to multilayer samples.

Measurements have shown that when the current frequency reaches $5 \mathrm{kHz}$, a sharp increase in resistance is observed in almost all samples of single-layer coils, with the exception of samples with 6 turns and inner diameters of 7 and $15 \mathrm{~mm}$. It can be assumed that these coils are less susceptible to negative effects due to the fewer turns. A coil with 6 turns and a $7 \mathrm{~mm}$ diameter has the lowest inductance value at a current frequency of $100 \mathrm{kHz}$. However, a sample with 6 turns and a $15 \mathrm{~mm}$ diameter has a constant inductance value over the entire frequency range from $25 \mathrm{~Hz}$ to $100 \mathrm{kHz}$. This fact makes the choice in favor of this coil preferable, because the difference in the voltage values required to provide a magnetic field strength of 20 Oe is insignificant.

Reel with optimal parameters planned use as a source of electromagnetic radiation in the hardware and software complex to study the effectiveness of shielding electromagnetic radiation. This hardware and software complex will have a unique structure and characteristics and will allow high-precision studies of the correlation of the chemical composition, structure, and shielding efficiency of a wide range of materials. 
In the future, it is planned to conduct research on the influence of various types of cores on the performance of emitting inductors.

\section{References}

1. Zhang C., Han Y., Zhang P., Song G., Zhou C. Research on modern radar emitter modeling technique under complex electromagnetic environment. The Journal of Engineering, 2019, vol. 2019, iss. 20, pp. 7134-7138.

DOI: $10.1049 /$ joe.2019.0579

2. Kechiev L.N., Akbashev B.B., Stepanov P.V. Shielding of technical means and shielding systems. M.: Iz-in. ITD Group Publ., 2010, 470 p.

3. Hawking M., Vasaktasari V., Sidki P. Metal and ceramic coatings: production, properties and application. Tr. from English M.: Mir Publ., 2000, 516 p.

DOI: $10.1016 / 0032-0633(59) 90029-7$

4. McLean J.S. Electric field generator incorporating a slow-wave structure. United States Patent. Appl. No.: 11/274.652. Date of Patent: Feb. 2, 2010. Patent No.: US 7,656,167 B1

5. Vaiser L.V., Kokorin B.I. Generator of electric and magnetic fields, a corresponding field detector, and a sample analyzer and treatment apparatus incorporating the field generator and/or field detector. Appl. No.: 10/396,440. Date of Patent: Aug. 3, 2004. Patent No.: US 6,770,023 B2

6. Gizatullin Z.M. Investigation of the effectiveness of shielding the body of a personal computer under intentional electromagnetic influences. Bulletin of the Kazan State Technical University. AN Tupolev, 2008, no. 1, pp. 28-31.

7. Shatalov D.P. A device for creating a powerful high-frequency alternating magnetic field. Invention patent. Application: 2008135378/09 from 03.09.2008. Published: 10.12.2009. Patent number: RU 2375722 C1.

8. Fadeev S.A. Inductor. Utility model patent. Application: 2011119668/07 dated 16.05.2011. Published: 10.01.2012. Patent number: RU 112496 U1.

9. Rysin A.V., Rysin O.V., Boykachev V.N., Nikiforov I.K. The paradox of the skin effect. Sciences of Europe, 2018, no. 28, pp. 52-61.

10. Kryukov A.V., Zakaryukin V.P., Sokolov V.Yu. Modeling of power supply systems with powerful busbars. Ed. A.V. Kryukov. Irkutsk: IrGUPS Publ., 2010, pp. 4-5. 